\title{
Fire Rehabilitation Using Native and Introduced Species: A Landscape Trial
}

\author{
Tyler W. Thompson, ${ }^{1}$ Bruce A. Roundy, ${ }^{2}$ E. Durant McArthur, ${ }^{3}$ \\ Brad D. Jessop, ${ }^{2}$ Blair Waldron, ${ }^{4}$ and James N. Davis ${ }^{5}$ \\ Authors are ${ }^{1}$ Habitat Biologist, Utah Division of Wildlife Resources, 1470 North Airport Rd Suite 1, Cedar City, \\ UT 84721-0606; ${ }^{2}$ Professor and Research Associate, Dept of Integrative Biology, Brigham Young University, Provo, UT 84602; \\ ${ }^{3}$ Research Leader, USDA Forest Service, Rocky Mountain Research Station, Shrub Sciences Laboratory, 735 N 500 E, Provo, UT \\ 84601; ${ }^{4}$ Research Geneticist, USDA Agricultural Research Service, Forage and Range Research Laboratory, Logan, \\ UT 84322-6300; and ${ }^{5}$ Range Trend Project Director, Utah Division of Wildlife Resources, 735 N 500 E, Provo, UT 84601.
}

\begin{abstract}
Following the 1999 Railroad Fire in Tintic Valley, Utah, we initiated a large-scale fire rehabilitation study comparing a predominately introduced species seed mix used by the US Department of Interior-Bureau of Land Management (BLM), a mix of native and introduced species provided by the US Department of Agriculture-Agricultural Research Service (ARS), and 2 native seed mixes (high and low diversity). Mixes were seeded with a rangeland drill on the big sagebrush (Artemisia tridentata var. wyomingensis [Beetle \& A. Young] Welsh) study area whereas the pinyon-juniper (Pinus edulis Engelm.-Juniperus osteosperma [Torr.] Little) woodland study area was aerially seeded followed by 1-way chaining. On drill-seeded plots and by the third year after seeding the native high-diversity mix $\left(16.4 \mathrm{~kg}\right.$ pure live seed [PLS] $\left.\cdot \mathrm{ha}^{-1}\right)$ had the highest seeded species cover $(11.5 \%)$ and density $\left(14\right.$ plants $\left.\cdot \mathrm{m}^{-2}\right)$. Both the BLM $\left(9.3 \mathrm{~kg}\right.$ PLS $\left.\cdot \mathrm{ha}^{-1}\right)$ and ARS $\left(9.1 \mathrm{~kg}\right.$ PLS $\left.\cdot \mathrm{ha}^{-1}\right)$ seed mixes had higher seeded species cover $(\mathrm{BLM}=8.5 \%, \mathrm{ARS}=8.2 \%)$ and density $\left(\mathrm{BLM}=8.4\right.$ and $\mathrm{ARS}=7.2$ plants $\left.\cdot \mathrm{m}^{-2}\right)$ than plots seeded to the low-diversity native $\operatorname{mix}\left(8 \mathrm{~kg} \mathrm{PLS} \cdot \mathrm{ha}^{-1}\right.$, cover $=3.8 \%$, density $=3.6$ plants $\left.\cdot \mathrm{m}^{-2}\right)$. Indian ricegrass $($ Achnatherum hymenoides $[$ Roemer and J. A. Schultes] Barkworth 'Nezpar') in the native high-diversity mix was especially successful on the sandy soils of the drill site, whereas seeds of other species may have been buried too deep for optimum emergence. Aerially-seeded and chained plots had similar and successful seeded species frequency, cover, and density (third-year average $=10.6 \%$ cover, 17.2 plants $\cdot \mathrm{m}^{-2}$ ) among all species mixes. All seeded plots had lower cover of annual species than unseeded plots, indicating that revegetation is necessary to reduce weed invasion following catastrophic wildfire in big sagebrush communities lacking residual perennial understory vegetation.
\end{abstract}

\section{Resumen}

Después del fuego del Ferrocarril ocurrido en 1999 en Tintic Valley Utah, iniciamos un estudio sobre rehabilitación a gran escala, comparando la mezcla de especies predominantemente introducidas, usada por la Oficina de Manejo de Tierras (BLM) del Departamento de Interior del los Estados Unidos de América, una mezcla de especies nativas e introducidas suministrada por el Servicio de Investigación Agrícola (ARS) del Departamento de Agricultura de Estados Unidos (USDA) y dos mezclas de especies nativas (alta y baja diversidad). Las mezclas fueron sembradas con una sembradora de pastizales en una área experimental de "Big sagebrush" (Artemisia tridentata var. wyomingensis [Beetle \& A. Young] Welsh), mientras que el área de estudio de bosque de "Pinyon-juniper" (Pinus edulis Engelm.-Juniperus osteosperma [Torr.] Little) fue sembrada en forma aérea seguida por cadeneo en una dirección. Al tercer año después de la siembra, las parcelas plantadas con la sembradora de pastizales y con la mezcla de alta diversidad $\left(16.4 \mathrm{~kg}\right.$ [semilla pura viable] SPV $\left.\cdot \mathrm{ha}^{-1}\right)$ tenían la mayor cobertura de especies sembradas $(11.5 \%)$ y la más alta densidad $\left(14\right.$ plantas $\left.\cdot \mathrm{m}^{-2}\right)$. Tanto la mezcla del BLM $\left(9.3 \mathrm{~kg} \mathrm{SPV} \cdot \mathrm{ha}^{-1}\right)$ como la del ARS $\left(9.1 \mathrm{~kg} \mathrm{SPV} \cdot \mathrm{ha}^{-1}\right)$ tuvieron mayor cobertura de especies sembradas $(\mathrm{BLM}=8.5 \%$, ARS $=8.2 \%)$ y densidad $\left(\mathrm{BLM}=8.4 \mathrm{y}\right.$ ARS $\left.=7.2 \mathrm{plantas} \cdot \mathrm{m}^{-2}\right)$ que las parcelas sembradas con la mezcla de especies nativas de baja diversidad $\left(8 \mathrm{~kg} \mathrm{SPV} \cdot \mathrm{ha}^{-1}\right.$, cobertura $=3.8 \%$, densidad $=3.6$ plantas $\cdot \mathrm{m}^{-2}$ ). En la mezcla de especies nativas de alta diversidad, el "Indian ricegrass" (Achnatherum hymenoides [Roemer and J. A. Schultes] Barkworth 'Nezpar') fue especialmente exitoso en los suelos arenosos del sitio plantado con la sembradora de pastizales, mientras que las semillas de otras especies pudieron haber sido enterradas muy profundo para la emergencia óptima. Las parcelas sembradas en forma aérea y con cadeneo tuvieron una frecuencia, cobertura y densidad de especies sembradas con éxito (promedio del tercer año $=10.6 \%$ cobertura, 17.2 plantas $\cdot \mathrm{m}^{-2}$ ) similares a todas las otras mezclas de especies. Todas las parcelas sembradas tuvieron una cobertura de especies anuales más baja que las parcelas sin sembrar, indicando que en las comunidades de "Big sagebrush," carentes de un estrato residual de vegetación perenne, la revegetación es necesaria para reducir la invasión de malezas después de un fuego no planeado de magnitud catastrófica.

Key Words: big sagebrush, pinyon-juniper, revegetation, weed suppression, wildfire

Research was funded through cooperative agreement JS1001005 between the USDA Forest Service, Rocky Mountain Research Station, Shrub Sciences Laboratory, Provo, Utah, and the USDI Bureau of Land Management, Utah State Office. Other cooperators include the Utah Division of Wildlife Resources Range Research and Great Basin Research Center with funds provided through Federal Aid Project W-82-R, and the USDA Agricultural Research Service Forage and Range Laboratory, Logan, Utah.

At the time of research, Thompson was a graduate student, Botany and Range Science, Brigham Young University, Provo, UT 84602.

Correspondence: Bruce Roundy, Dept of Integrative Biology, 401 WIDB, Brigham Young University, Provo, UT 84602. Email: bruce_roundy@byu.edu

Manuscript received 11 July 2005; manuscript accepted 22 February 2006. 


\section{INTRODUCTION}

Throughout the Great Basin, the encroachment of cheatgrass (Bromus tectorum L.) and other flammable weeds into big sagebrush (Artemisia tridentata Nutt.) communities has drastically increased the frequency, intensity, and scale of fire (Pyke et al. 2003). On average, 264659 ha of land burn in the Great Basin each year (NIFC 2005). In the absence of postfire intervention, many Great Basin ecosystems are subject to severe environmental degradation by annual weed dominance and exclusion of native species (Young and Evans 1978). This results in a loss of critical wildlife habitat, decreased biological diversity, increased susceptibility to erosion, and impaired ecosystem function (Monsen and Kitchen 1994; West and Young 2000). The once-extensive sagebrush biome is now considered one of the most endangered in the United States (Noss et al. 1995). Following wildfires, federal land management agencies receive funding from the Burned Area Emergency Response (BAER) program to implement practices that "protect life, property, and critical natural and cultural resources" (USDA-FS 2005). This may include rehabilitation efforts that preserve soil, water, and vegetation resources; prevent unacceptable on-site and off-site erosional damage to the watershed; reduce the invasion and establishment of undesirable plant species; and ensure that Land Use Plan objectives are met (MacDonald 1999; USDI-Bureau of Land Management 1999). Reestablishing desirable vegetation on these sites is often the most effective means of reaching these goals (Brown and Amacher 1999). Historically, introduced species such as crested wheatgrass (Agropyron cristatum [L.] Gaertner), intermediate wheatgrass (Thynopyrum intermedium [Host] Barkworth and D. R. Dewey), smooth brome (Bromus inermis Leysser), and Russian wildrye (Psathrostachys juncea [Fisch.] Nevski) were used successfully to meet the goals of soil conservation and forage production in rangeland revegetation (Roundy et al. 1997). Currently, emphasis on maintaining or increasing native species diversity and restoring ecosystem processes has led to greater use of native species. Previous and current hesitancy to use native seed for large-scale fire rehabilitation projects is associated with increased cost, lack of availability (Roundy et al. 1997), and the perception that natives do not establish or compete as well as introduced species on lands at risk to rapid weed invasion. Despite a well-structured and growing native seed industry that has increased the availability and decreased the cost of many native species (Waters and Shaw 2003), native seed costs are still greater than those of introduced species. In a study evaluating the use of native vs. introduced species in Bureau of Land Management (BLM) fire rehabilitation projects in the Great Basin, the percentage native seeds of total bulk seed mass purchased rose from about 20 to $40 \%$ from 1988 to 1999 (Pyke et al. 2003). Of the over $1000000 \mathrm{~kg}$ of bulk seed mass purchased by the BLM Boise seed warehouse for the second seed buy in 2005, 51\% was of native species (Scott M. Lambert, personal communication, 27 September 2005). Clearly, increased emphasis on use of native plants necessitates a better understanding of how to establish these species on a large scale (Richards et al. 1998).

There is evidence that some native species may establish and compete as well as some introduced species (Pyke et al. 2003; Huber-Sannwald and Pyke 2005). Native species, especially bluebunch and western wheatgrass (Pseudoreogneria spicata
[Pursh] A. Löve and Pascopyrum smithii [Rybd.] A. Löve), have been sown successfully on large-scale rehabilitation projects for over 45 years by the Utah Division of Wildlife Resources, including 162000 ha since 1958 (S.C. Walker, personal communication, 2002). Pyke et al. (2003) found similar composition for native and introduced plants sown in fire rehabilitation projects throughout the Great Basin since the early 1990s, despite the fact that introduced species were seeded in greater proportion than natives. Natives may have limited establishment when sown with more competitive introduced species that have high initial establishment, such as crested wheatgrass, but establish better when sown with less readily established species such as Russian wildrye (Waldron et al. 2005).

Lack of data supporting the use of native species on largescale projects contributes to their limited use on federal lands. Studies comparing native to introduced species have commonly used single-species comparisons on small-scale research plots. Such studies have often highlighted the limitations of native species establishment on semiarid rangelands when compared to introduced species (Asay et al. 2001). Because small plot sowing methods may differ from large, operational-scale methods, results may not be applicable to large-scale rehabilitation projects. Following a 1999 wildfire in western Utah, we compared establishment of native and introduced species sown in 4 different seed mixes at an operational scale using methods typical of landscape-scale fire rehabilitation projects. Our hypothesis was that the mix of species in native seed mixes would establish as well as the mix of species in predominately introduced species mixes, but that higher total seeding rates are necessary for them to do so.

\section{METHODS}

\section{Study Areas}

In July 1999, railroad track grinders ignited the Railroad Fire in Tintic Valley, Juab County, Utah, burning nearly 25000 ha. The preburn vegetation included mostly pinyon-juniper (Pinus edulis Engelm. and Juniperus osteosperma [Torr.] Little) woodlands at the upper elevations and Wyoming big sagebrush (Artemisia tridentata var. wyomingensis [Beetle \& A. Young] Welsh)-perennial grass communities at the lower elevations.

We selected 2 study areas at different elevations within the 1999 Railroad Burn that were representative of lands that are either typically drill-seeded or aerially-seeded followed by 1 way chaining. The lower elevation Jericho area (lat $39^{\circ} 42^{\prime}-$ $45^{\prime} \mathrm{N}$, long $112^{\circ} 11^{\prime}-17^{\prime} \mathrm{W}$ ) ranges from $1650 \mathrm{~m}$ to $1680 \mathrm{~m}$, as an ecological site receives $254-305 \mathrm{~mm}$ of precipitation annually (USDA-NRCS 1984), and supported a Wyoming big sagebrush-grass community prior to burning. Soils are of the Truesdale series of coarse-loamy, mixed, mesic Haploxerollic Durorthids and the Linoyer series of coarse-silty, mixed (calcareous), mesic Xeric Torrifluvents, on alluvial fans and lake terraces (USDA-NRCS 1984). High-temperature burns left the area with little or no residual vegetation or ground cover. In this area, a few scattered juniper trees were cut with a chainsaw and cleared to allow drill seeding.

The Mud Springs study area (lat $39^{\circ} 51^{\prime}-54^{\prime} \mathrm{N}$, long $112^{\circ} 11^{\prime}-$ $\left.15^{\prime} \mathrm{W}\right)$ ranges in elevation from $1769 \mathrm{~m}$ to $1799 \mathrm{~m}$, as an ecological site receives $305-356 \mathrm{~mm}$ of precipitation annually (USDA-NRCS 1984), and was pinyon and juniper woodland 
Table 1. Species used in various seed mixes in drill-seeded and aerially seeded fire rehabilitation sites in Tintic Valley, Utah. ${ }^{1}$

\begin{tabular}{|c|c|c|c|c|c|c|c|c|c|c|c|}
\hline \multirow[b]{2}{*}{ Origin } & \multirow[b]{2}{*}{ Species } & \multirow[b]{2}{*}{ Variety } & \multirow[b]{2}{*}{ PLS } & \multicolumn{2}{|c|}{ BLM } & \multicolumn{2}{|c|}{ ARS } & \multicolumn{2}{|c|}{$\mathrm{NH}$} & \multicolumn{2}{|c|}{ NL } \\
\hline & & & & Drill & Aerial & Drill & Aerial & Drill & Aerial & Drill & Aerial \\
\hline $\bar{N}$ & Great Basin wildrye & Magnar & 0.86 & - & - & - & - & 2.2 & 3 & - & - \\
\hline N & Bluebunch wheatgrass & Whitmar & $0.85 \mathrm{E}$ & - & - & - & - & 2.2 & 4.5 & 2.2 & 4.5 \\
\hline N & Bluebunch wheatgrass & Goldar & 0.86 & - & 3 & - & - & 2.2 & 4.5 & 2.2 & 4.5 \\
\hline N & Bluebunch wheatgrass & Secar & 0.89 & - & - & 1.3 & 2.5 & - & - & - & - \\
\hline I & Crested wheatgrass & Hycrest & 0.85 & 2.2 & 4.5 & - & - & - & - & - & - \\
\hline I & Hybrid crested wheatgrass & CD II & 0.93 & - & - & 1.8 & 3.6 & - & - & - & - \\
\hline N & Indian ricegrass & Rimrock & 0.92 & - & - & 0.6 & 1.2 & - & - & - & - \\
\hline N & Indian ricegrass & Nezpar E & 0.85 & - & - & - & - & 2.2 & 3 & 2.2 & 3 \\
\hline N & Needle and thread & VNS & 0.88 & - & - & - & - & 2.2 & 3 & - & - \\
\hline N & Pubescent wheatgrass & Luna & 0.92 & 2.2 & 3 & - & - & - & - & - & - \\
\hline I & Russian wildrye & Bozoisky & 0.86 & 2.2 & 3 & 1.5 & 3 & - & - & - & - \\
\hline N & Sandberg bluegrass & - & 0.85 & - & - & - & - & 2.2 & 3 & & 1.5 \\
\hline I & Siberian wheatgrass & Vavilov & 0.89 & - & - & 1.9 & 3.8 & - & - & - & - \\
\hline I & Smooth brome & Lincoln & 0.81 & - & 3 & - & - & - & - & - & - \\
\hline N & Squirreltail & VNS & 0.77 & - & - & - & - & 2.2 & 3 & - & - \\
\hline I & Tall wheatgrass & Alkar & 0.83 & 2.2 & 3 & - & - & - & - & - & - \\
\hline N & Thickspike wheatgrass & Critana & 0.93 & - & - & 0.6 & 1.2 & - & - & - & - \\
\hline N & Western wheatgrass & Rosanna & $0.85 \mathrm{E}$ & - & - & 1.2 & 2.4 & 2.2 & 3 & 1.1 & 3 \\
\hline N & Western wheatgrass & Aribba & 0.88 & 1.1 & - & - & - & - & - & - & - \\
\hline I & Alfalfa & Rangelander & 0.56 & - & - & 1.5 & 3 & - & - & - & - \\
\hline I & Alfalfa_inoculated & Ladak & 0.92 & 0.6 & - & - & - & - & - & - & - \\
\hline I & Forage kochia & Immigrant & 0.71 & - & - & 0.4 & 0.8 & - & - & - & - \\
\hline N & Antelope bitterbrush & - & $0.8 \mathrm{E}$ & - & + & - & + & 1.1 & + & 1.1 & + \\
\hline N & Fourwing saltbush & - & 0.32 & 0.6 & + & - & + & 1.1 & + & 1.1 & + \\
\hline N & Wyoming big sagebrush & - & 0.14 & - & - & - & - & 2.2 & 3 & 1.1 & 1.5 \\
\hline \multicolumn{12}{|c|}{ Total rate excluding dribbler mix $\left(\mathrm{kg} \cdot \mathrm{ha}^{-1}\right)$} \\
\hline PLS & & & & 9.3 & 16.7 & 9.1 & 18 & 16.4 & 23.3 & 8 & 14.3 \\
\hline Bulk & & & & 11.1 & 19.5 & 10.8 & 21.5 & 22 & 30 & 11 & 18 \\
\hline Cost $(\$ / h a)$ & & & & $\$ 11.90$ & $\$ 17.74$ & $\$ 18.20$ & $\$ 36.41$ & $\$ 94.31$ & $\$ 124.76$ & $\$ 35.10$ & $\$ 53.22$ \\
\hline
\end{tabular}

${ }^{1}$ BLM indicates Bureau of Land Management; ARS, Agricultural Research Service; NH, native high; NL, native low; PLS, pure live seed; N, native; E, PLS percentage unknown but expected to be at least what is listed; I, introduced; +, included in dribbler mix and seeded at 2.2 total $\mathrm{kg} / \mathrm{ha}$ at a cost of $\$ 6.96 / \mathrm{ha}$.

prior to burning. Soils are of the Shablis series of loamy, mixed, mesic, shallow Haploxerollic Duorthids and of the Borvant series of loamy-skeletal, carbonatic, mesic, shallow Aridic Petrocalcic Palexerolls, on alluvial fans and lake terraces (USDA-NRCS 1984). Steep slopes and high tree density precluded the use of a rangeland drill, so plots were aerially seeded followed by 1-way chaining with an "Ely" style chain (Wiedemann 2005). Only a few small scattered patches of unburned trees and other vegetation survived the high-intensity fire.

\section{Seed Mixes and Experimental Design}

We established 5 4.9-ha replications $(228 \times 213 \mathrm{~m})$ at the Jericho drill site and 5 7.8-ha replications $(365 \mathrm{~m} \times 213 \mathrm{~m})$ at the Mud Springs aerial site. We selected replications to be similar in apparent preburn vegetation conditions, as evidenced by burned tree density and residual understory cover. Replications were divided into 5 equal strips and randomly assigned 1 of the 4 seed mixes (Table 1) or left unseeded as a control (USC). The BLM drill and aerial seed mixes supplied by the BLM Fillmore field office were composed primarily of introduced grasses. Species in these mixes have established successfully in fire rehabilitation projects in Tintic Valley (Ott et al. 2003). The Agricultural Research Service (ARS) seed mixes, supplied by the Forage and Range Research Laboratory in Logan, Utah, contained both native and introduced species and incorporated several improved plant materials and varieties. The native high $(\mathrm{NH})$ diversity aerial and drill mixes included up to 8 grass species or accessions and 3 shrubs, and were seeded at high individual species rates and with additional species to test our hypothesis that high rates would be necessary to equal the success of seeding introduced species. The native low (NL) diversity aerial and drill mixes constituted a subset of species from the NH mix and were formulated to be applied at rates comparable to those recommended for the BLM and ARS mixes.

\section{Rangeland Drill Seeding}

The Jericho replications were seeded on 12 November 1999 using 4 rangeland drills. Each drill carried only the seed mix for which it was precalibrated. All drills were outfitted with 3 seed boxes that could be individually adjusted to seed at different rates. This allowed species within a mix to be separated according to seed size or morphology. The main seed box on each drill was used exclusively for grasses. The second box was used to seed fourwing saltbush (Atriplex canescens [Pursh.] Nutt.) and antelope bitterbrush (Purshia tridentata [Pursh.] DC), 
which have larger seeds. Wyoming big sagebrush seed was sown from a third "trashy seed" box, which uses special augers to push the seed towards a center "pick-wheel" that rotates downward, grabbing the seed and forcing it into the seeding tubes (Wiedemann 2005). The tubes from this box were disconnected from the disc assembly to allow sagebrush seed to fall onto the soil surface. All species in the BLM mix were combined and seeded from 1 box, which is typical of BLM practices for the Fillmore field office. All species in the ARS drill mix were combined, with the exception of forage kochia (Kochia prostrata [L.] Schrad.), which was seeded onto the soil surface from a separate box. Species in the NL and NH drill mixes were separated into 3 submixes for use in different boxes on the rangeland drill. Shrubs and grasses were sown in different rows to increase shrub survival by limiting competition with grasses at the seedling stage. The native seed drills limited the large seeded shrub mix and sagebrush seed to rows 3 and 8 on the drill, which was equipped with 10 seed-drops. The native grass mixes were seeded through the remaining seeddrops. This configuration resulted in 1 row of shrubs between 4 rows of native grass. Four-wheel-drive tractors were used to pull the drills through each replication in a manner consistent with standard operations of the BLM. All drills used in this study were equipped with standard concave discs without depth-regulator bands.

\section{Aerial Seeding}

The Mud Springs site was aerially seeded on 19 November 1999. With the exception of antelope bitterbrush and fourwing saltbush, which were applied during the chaining process using a seed dribbler, species within each aerial seed mix were all mixed and seeded together. Although the BLM typically uses a fixed-wing aircraft for its seeding operations, we used a helicopter for increased maneuverability and more precise seed placement on the narrow study plots. Using a helicopter also allowed enough room for a team member to direct operations from the air and saved time by facilitating on-site loading and changing of the seed mixes.

The helicopter was equipped with a gravity-fed broadcast seeder that could be remotely operated by the pilot. The broadcast seeder was calibrated to release a desired amount of seed in a specific amount of time based on aircraft speed and seeding swath width. At the time of application, the speed of the helicopter was adjusted between 74 and $124 \mathrm{~km} \cdot \mathrm{h}^{-1}$ to produce the desired seeding rate for each seed mix. Prior to seeding, flight lines for each seeding pass were identified and marked with large fluorescent colored flags to give the pilot a clear line to follow. A continuous swath of approximately $55 \mathrm{~m}$ was seeded for each mix within a replication.

Following aerial seed application, plots were 1-way chained using 2 crawler tractors (D8 and D9) pulling an Ely-style chain. Ely chains have a section of railroad rail welded perpendicular to each link to increase soil disturbance and better cover seed (Wiedemann 2005). Using a seed dribbler, a mix of antelope bitterbrush and fourwing saltbush seed was applied at a rate of $2 \mathrm{~kg} \cdot \mathrm{ha}^{-1}$ across all treatments except the control. Seed dribblers utilize a rubber tire in contact with the track of the crawler tractor to power a seeding mechanism that drops seed onto the crawler track. The seed falls on the ground in front of the track and is firmly pressed into the soil by the weight of the tractor (Plummer et al. 1968). Chaining begun in late November was interrupted by winter weather and was completed in February.

\section{Vegetation Sampling}

We collected cover, frequency, and density data from $0.25-\mathrm{m}^{2}$ quadrats along 5 30-m transects bisecting each treatment plot. Twenty quadrats were randomly placed and sampled along each of the 5 transects, for a total of 100 quadrats per treatment in each replication.

Within each quadrat we visually estimated percent cover of litter, bare ground, and plant canopy cover by species. All cover estimates were based on the following 8 cover classes: $1=0.01 \%-1 \%, 2=1.1 \%-5 \%, 3=5.1 \%-15 \%, 4=15.1 \%-$ $25 \%, 5=25.1-50 \%, 6=50.1 \%-75 \%, 7=75.1 \%-95 \%$, and $8=95.1 \%-100 \%$. Percent cover was determined by summing all the midpoints for each cover class and dividing by the total number of quadrats for the site. Nested frequency was determined by dividing the quadrat into the following subquadrats: $5=1 \%$ of the area, $4=5 \%$ of the area, $3=25 \%$ of the area, $2=50 \%$ of the area, and $1=$ the remainder of the quadrat. Nested frequency scores were determined for each species and ground cover type according to the smallest subquadrat in which they were rooted or positioned on the ground. For example, if a species was rooted in the $25 \%$ subquadrat, but not the $5 \%$ subquadrat, it received a score of 3 for that quadrat. Sum of nested frequency (SNF) was calculated for each species and ground cover type by summing its scores in each quadrat for the entire site. This value gives a measurement of relative abundance for each species and cover category (Mosley et al. 1986; Smith et al. 1986, 1987). Such values are especially useful in monitoring vegetation trend and changes in community composition through time.

We counted grass and forb densities of each species rooted in each quadrat. Perennial bunchgrasses were counted as 1 individual and abundant annual species with over 50 individuals were estimated. We counted density of all shrub species within a 0.004 -ha strip centered over the length of each $30-\mathrm{m}$ transect. Vegetation parameters for all plots were measured within a 1-week time period in late August of 2000, 2001, and 2002.

\section{Other Sampling}

We collected soil samples to determine percentages of sand, silt, and clay (Bouyoucos 1962) for all treatments within each replication. Samples were taken at depths of $0-40 \mathrm{~cm}$ at 6 locations within a plot and combined into 1 composite sample. Soil samples were collected 1 year after seeding in summer 2000.

We also measured soil erosion and deposition using point or stake measurements (Hadley and Lusby 1967; Haight 1977; Takei et al. 1981). In each treatment within a replication, we placed 16 stakes with metal washers. Initial and subsequent measurements were recorded from the top of the stake to the washer on the soil surface. Measurements were taken periodically and averaged across the study sites.

We collected precipitation data at the Jericho drill site using a CR-10 micrologger (Campbell Scientific Inc., Logan, UT). Precipitation data for the Mud Springs study area were obtained from the Mud Springs Remote Automated Weather 
Station (Western Regional Climate Center 2005), which is located approximately $0.5 \mathrm{~km}$ from the aerial seeding sites.

\section{Statistical Analysis}

We used mixed model analysis (Littell et al. 1996) with year as a repeated measure to determine significant differences $(P<0.05)$ among treatments. Seed mix treatment was considered fixed and replication was considered a random effect. Differences among seed mixes for vegetation variables were determined using the Tukey-Kramer mean separation technique. Significant differences in soil variables and point erosion data were determined using the general linear model (GLM) technique (SAS Institute 1987) with Tukey-Kramer $(P<0.05)$ used as a mean separation technique.

\section{RESULTS}

Above-average winter, near-average May and June, and high October precipitation in 2000 supported initial seedling establishment from the fall 1999 seeding (Fig. 1). Precipitation for 2001 and 2002 was less than half of the 2000 total for both study areas and substantially less than the 30 -year mean during the critical spring and early summer months. Although the yearly totals for 2001 and 2002 were extremely low for both areas, the early spring (March and April) precipitation was similar to that recorded in 2000 for 2001 on both the Jericho and Mud Springs study areas, and similar in 2002 to 2000 for that time period for Mud Springs (Fig. 1).

\section{Drill Seeding}

There was very little emergence of seeded species in replications 4 and 5 at the Jericho site. On these replications, vegetation was dominated by annuals and seeded species cover, frequency, and density were not statistically different $(P>0.05)$ from those of the unseeded controls (USC). A higher percentage of sand in these replications $(64 \%)$ compared to the others $(54 \%)$ and drilling these replications perpendicular to prevailing winds without depth bands may have resulted in seeds being buried too deep for seedlings to emerge. Because of differences in soil texture and the lack of emergent seedlings, we excluded replications 4 and 5 from the analysis. All drill data reported hereafter are for replications 1-3. Neither drill-seeded nor unseeded plots showed significant signs of erosion or deposition throughout the study, as evidenced by little difference $(<2$ $\mathrm{mm}$ ) in the height of washers on erosion measurement stakes.

All vegetation variables showed significant response to year $(P<0.05)$ and there were significant differences for mix and the year $\times$ mix interaction for seeded species cover $(P=0.004$, $P=0.0459)$ and density $(P=0.0035, P=0.0084$; Table 2$)$. Frequency of seeded species was significant by $\operatorname{mix}(P=0.0028)$ but the year $\times$ mix interaction was not significant $(P=0.1168)$. The NL mix had consistently lower cover, frequency, and density of seeded species and a higher density of annual weeds compared to the other seed mixes (Fig. 2; Table 2). Across all years, cover and frequency of seeded species were similar for the NH, ARS, and BLM mixes, with the $\mathrm{NH}$ mix having a greater density than that of the BLM and ARS mixes. The BLM mix plots had greater density over all years than the ARS mix plots, but the 2 mixes were similar in cover, with $<1 \%$
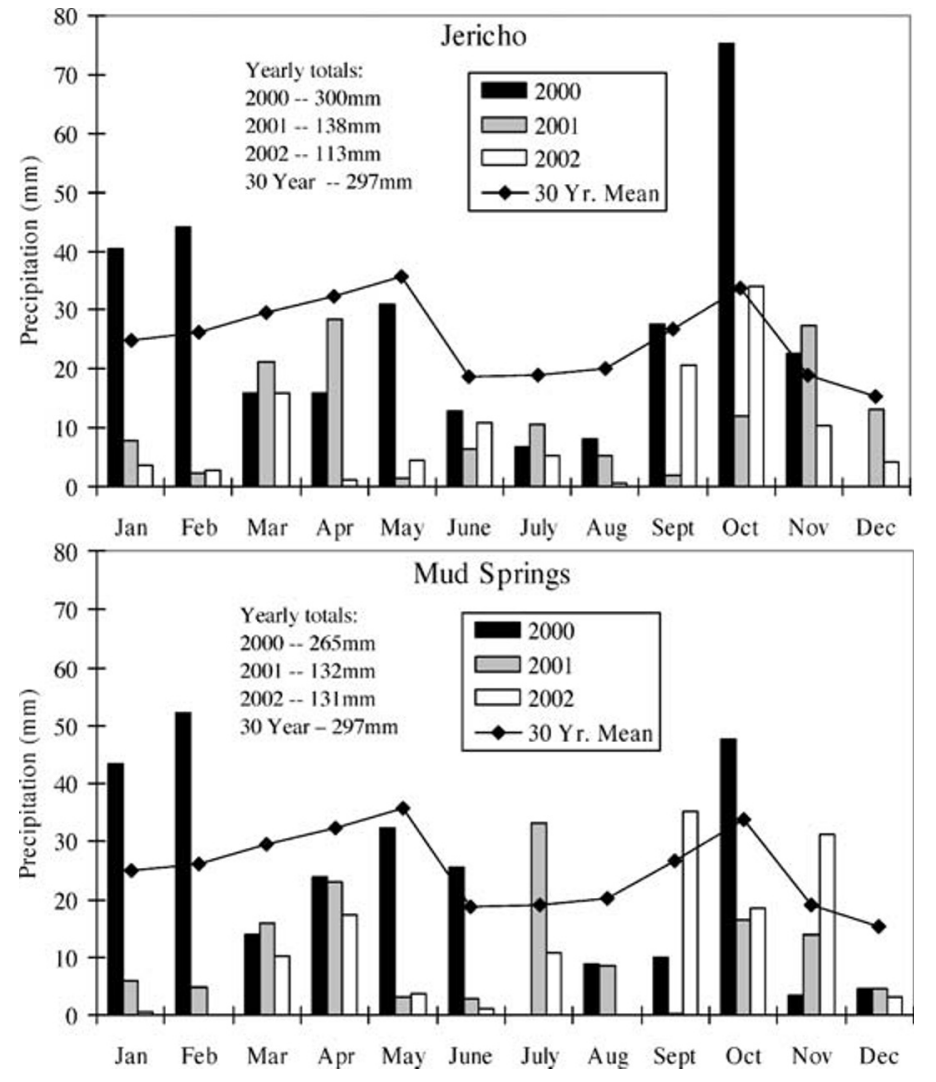

Figure 1. Monthly precipitation for Jericho and Mud Springs study areas in Tintic Valley, Utah. Thirty-year mean is from the Little Sahara weather station south of Jericho. Mud Springs monthly data are from Western Regional Climate Center (2005).

difference in any year. Cover and density of residual vegetation was limited and did not vary among seeded plots.

Even though the NL mix did not establish as well as the others, there were significantly fewer annual weeds in the NL plots than in the unseeded control (USC) plots in 2002 (Fig. 2; Table 2). Total annual cover increased from $10.6 \%$ in 2000 to $32.0 \%$ in 2002 in control plots, but declined in all seeded plots including NL. This indicated that even minimal establishment of seeded species suppressed annual weeds.

Cheatgrass and 3 annual forbs, Russian thistle (Salsola pestifer A Nels.), desert alyssum (Alyssum desertorum Stafp), and an annual species of gilia (Gilia spp. Ruiz and Pavon), made up the majority of plant density and cover throughout the study. Between 2001 and 2002, density of annuals more than doubled in ARS, BLM, and NH plots and tripled in NL and unseeded plots $(\mathrm{NL}=75.6$ to 273.6 and $\mathrm{USC}=86.8$ to 296 plants $\cdot \mathrm{m}^{-2}$ ), whereas there was little change in seeded species density. Despite the increased number of annual plants in seeded plots, seeded species cover exceeded or was nearly equal to annual cover in ARS, BLM, and NH plots in 2002 (Fig. 2).

In the ARS and BLM mixes, crested wheatgrass had greater establishment than any other species (Fig. 3). BLM plots also had substantial growth of tall wheatgrass (Thinopyrum ponticum [Podp.] Z.-W. Lui and R.-C. Wang) and pubescent wheatgrass (Thinopyrum intermedium [Host.] Barkworth \& D. R. Dewey). ARS plots included some wheatgrasses that were not easily distinguished from each other, including thickspike 
Table 2. Significance of vegetation variables measured in 2000,2001 , and 2002 for different seed mixes drill-seeded for fire rehabilitation in fall 1999 on a previous Wyoming big sagebrush community at Jericho, Tintic Valley, Utah. ${ }^{1}$

\begin{tabular}{|c|c|c|c|c|c|}
\hline \multirow[b]{2}{*}{ Variable } & \multicolumn{3}{|c|}{$P$ Values } & \multicolumn{2}{|c|}{ Order (based on Tukey 0.05) } \\
\hline & Year & Mix & Year $\times$ Mix & Mix & Year $\times$ Mix \\
\hline \multicolumn{6}{|l|}{ Cover } \\
\hline Total perennial & $<0.0001$ & $<0.0001$ & $<0.0001$ & $\mathrm{ARS}=\mathrm{BLM}=\mathrm{NH}>\mathrm{NL}=\mathrm{USC}$ & $\mathrm{NH}>\mathrm{BLM}>\mathrm{ARS}>\mathrm{NL}>\mathrm{USC}$ \\
\hline Total annual & $<0.0001$ & $<0.0001$ & $<0.0001$ & $\mathrm{USC}>\mathrm{NL}>\mathrm{ARS}=\mathrm{BLM}=\mathrm{NH}$ & $\mathrm{USC}>\mathrm{NL}>\mathrm{ARS}=\mathrm{BLM}=\mathrm{NH}$ \\
\hline Perennial grass & $<0.0001$ & $<0.0001$ & $<0.0001$ & $\mathrm{NH}>\mathrm{BLM}>\mathrm{ARS}>\mathrm{NL}>\mathrm{USC}$ & $\mathrm{NH}>\mathrm{BLM}>\mathrm{ARS}>\mathrm{NL}>\mathrm{USC}$ \\
\hline Annual forb & 0.0001 & 0.0003 & 0.0002 & $\mathrm{USC}>\mathrm{NL}>\mathrm{ARS}>\mathrm{BLM}=\mathrm{NH}$ & $\mathrm{USC}>\mathrm{NL}>\mathrm{ARS}=\mathrm{BLM}=\mathrm{NH}$ \\
\hline Seeded species & $<0.0001$ & 0.004 & 0.0459 & $\mathrm{ARS}=\mathrm{BLM}=\mathrm{NH}>\mathrm{NL}$ & $\mathrm{NH}>\mathrm{ARS}=\mathrm{BLM}>\mathrm{NL}$ \\
\hline Bluebunch wheatgrass & $<0.0001$ & $<0.0001$ & $<0.0001$ & $\mathrm{NH}>\mathrm{NL}>\mathrm{ARS}=\mathrm{BLM}=\mathrm{USC}$ & $\mathrm{NH}>\mathrm{NL}>\mathrm{ARS}>\mathrm{BLM}=\mathrm{USC}$ \\
\hline Desert alyssum & $<0.0001$ & 0.0226 & 0.0047 & $\mathrm{USC}>\mathrm{ARS}=\mathrm{NL}>\mathrm{BLM}=\mathrm{NH}$ & $\mathrm{USC}>\mathrm{ARS}=\mathrm{NH}=\mathrm{NL}>\mathrm{BLM}$ \\
\hline Gilia spp. & $<0.0001$ & 0.9223 & 0.9859 & - & - \\
\hline Total perennial & $<0.0001$ & $<0.0001$ & 0.289 & $\mathrm{ARS}=\mathrm{BLM}=\mathrm{NH}>\mathrm{NL}=\mathrm{USC}$ & - \\
\hline Total annual & $<0.0001$ & 0.0092 & 0.0006 & $\mathrm{USC}>\mathrm{NL}>\mathrm{ARS}=\mathrm{BLM}=\mathrm{NH}$ & $\mathrm{NL}=\mathrm{USC}>\mathrm{ARS}>\mathrm{NH}>\mathrm{BLM}$ \\
\hline Perennial grass & $<0.0001$ & $<0.0001$ & 0.0581 & $\mathrm{NH}>\mathrm{BLM}>\mathrm{ARS}>\mathrm{NL}>\mathrm{USC}$ & - \\
\hline Annual grass & $<0.0001$ & 0.0082 & $<0.0001$ & $\mathrm{NL}=\mathrm{USC}>\mathrm{ARS}=\mathrm{NH}>\mathrm{BLM}$ & $\mathrm{NL}=\mathrm{USC}>\mathrm{ARS}>\mathrm{NH}>\mathrm{BLM}$ \\
\hline Perennial forb & $<0.0001$ & 0.0091 & 0.7032 & $\mathrm{BLM}>\mathrm{ARS}>\mathrm{NH}=\mathrm{NL}=\mathrm{USC}$ & - \\
\hline Annual forb & $<0.0001$ & 0.0174 & 0.0272 & $\mathrm{USC}>\mathrm{BLM}=\mathrm{NL}>\mathrm{ARS}=\mathrm{NH}$ & $\mathrm{USC}>\mathrm{NL}>\mathrm{BLM}>\mathrm{ARS}=\mathrm{NH}$ \\
\hline Seeded species & $<0.0001$ & 0.0028 & 0.1168 & $\mathrm{ARS}=\mathrm{BLM}=\mathrm{NH}>\mathrm{NL}$ & - \\
\hline Bluebunch wheatgrass & 0.0015 & 0.0007 & 0.0919 & $\mathrm{NH}>\mathrm{ARS}=\mathrm{BLM}=\mathrm{NL}=\mathrm{USC}$ & - \\
\hline Desert alyssum & $<0.0001$ & 0.5806 & 0.2494 & - & - \\
\hline Gilia spp. & $<0.0001$ & 0.8746 & 0.8746 & - & - \\
\hline Russian thistle & $<0.0001$ & 0.0114 & $<0.0001$ & $\mathrm{USC}>\mathrm{NL}>\mathrm{ARS}=\mathrm{BLM}=\mathrm{NH}$ & $\mathrm{USC}=\mathrm{NL}>\mathrm{BLM}>\mathrm{NH}>\mathrm{ARS}$ \\
\hline Annual forb & $<0.0001$ & 0.144 & 0.376 & - & - \\
\hline Seeded species & $<0.0001$ & 0.0035 & 0.0084 & $\mathrm{NH}>\mathrm{BLM}>\mathrm{ARS}>\mathrm{NL}$ & $\mathrm{NH}>\mathrm{BLM}>\mathrm{ARS}>\mathrm{NL}$ \\
\hline Bluebunch wheatgrass & 0.0011 & 0.0003 & 0.0187 & $\mathrm{NH}>\mathrm{ARS}=\mathrm{BLM}=\mathrm{NL}=\mathrm{USC}$ & $\mathrm{NH}>\mathrm{ARS}=\mathrm{BLM}=\mathrm{NL}=\mathrm{USC}$ \\
\hline Desert alyssum & $<0.0001$ & 0.5411 & 0.8948 & - & - \\
\hline Gilia spp. & $<0.0001$ & 0.9247 & 0.9745 & - & - \\
\hline Russian thistle & $<0.0001$ & 0.0019 & $<0.0001$ & $\mathrm{NL}=\mathrm{USC}>\mathrm{ARS}=\mathrm{BLM}=\mathrm{NH}$ & $\mathrm{NL}=\mathrm{USC}>\mathrm{ARS}=\mathrm{BLM}=\mathrm{NH}$ \\
\hline \multicolumn{6}{|c|}{ Degrees of freedom (seeded species category) } \\
\hline Numerator & 2 & 3 & 6 & & \\
\hline Denominator & 16 & 6 & 16 & & \\
\hline \multicolumn{6}{|c|}{ Degrees of freedom (all others) } \\
\hline Numerator & 2 & 4 & 8 & & \\
\hline Denominator & 20 & 8 & 20 & & \\
\hline
\end{tabular}

${ }^{1}$ USC indicates unseeded control; NL, native low; NH, native high; ARS, Agricultural Research Service; BLM, Bureau of Land Management. Order for the year $\times$ mix column is for 2002.

wheatgrass (Agropyron dasystachyum [Hook.] Scribn), Siberian wheatgrass (Agropyron sibiricum [Willd.] Beauv.), Hycrest crested wheatgrass, a hybrid of Agropyron cistatum (L.) Gaertner and Agropyron desertorum (Fisch. exLink) Schultes, and CD II crested wheatgrass, a synthetic derivative of Hycrest. These wheatgrasses may have contributed to the total cover attributed to crested wheatgrass (Fig. 3). In NL and NH plots, Indian ricegrass (Achnatherum bymenoides [Roemer and J. A. Schultes] Barkworth) var. 'Nezpar' was most successful, contributing more cover than all other species combined. Bluebunch wheatgrass and western wheatgrass also established well. 

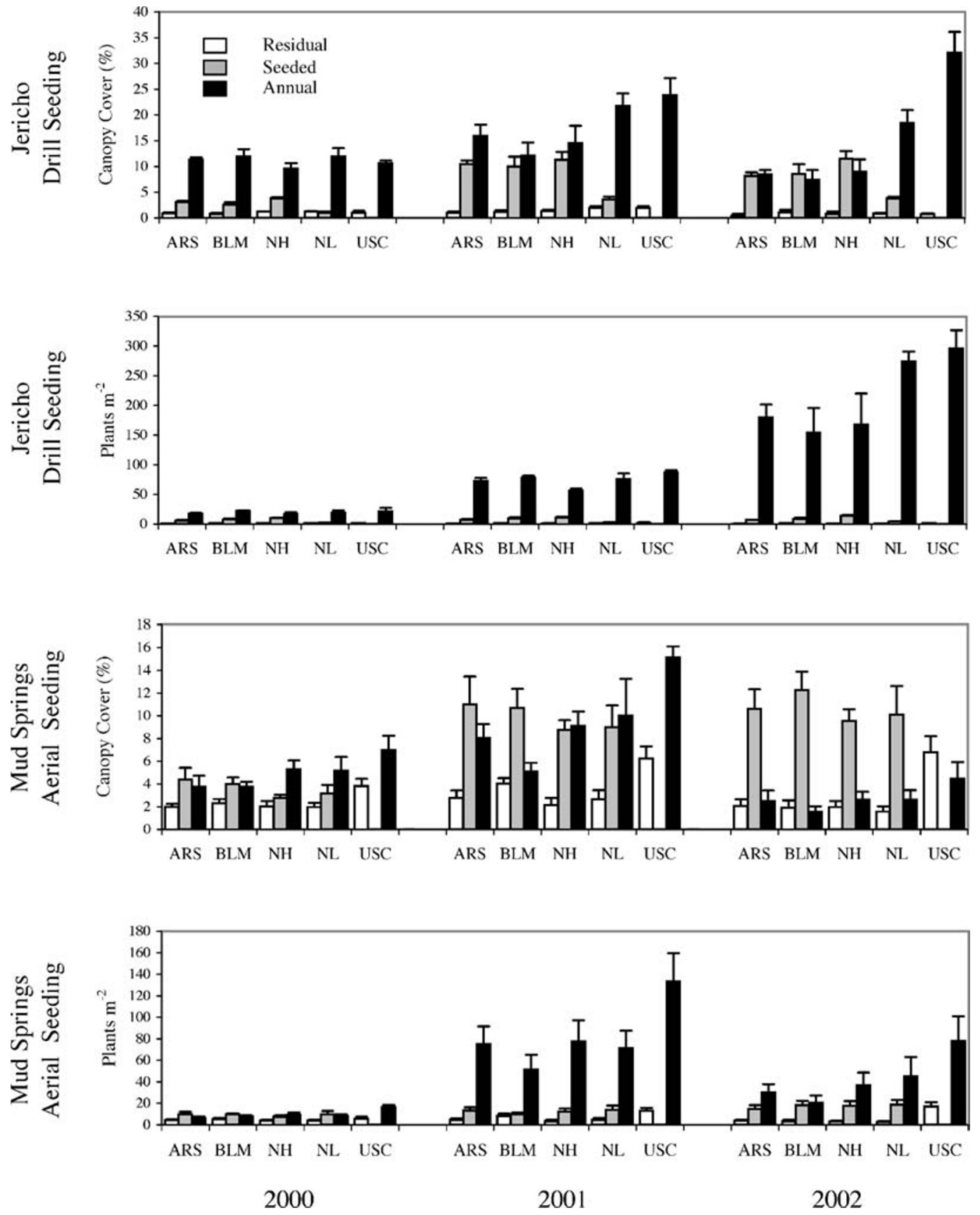

Figure 2. Postfire vegetation cover and density of seeded, residual, and annual species following drill and aerial seeding at 2 areas in Tintic Valley, Utah. ARS indicates Agricultural Research Service mix; BLM, Bureau of Land Management mix; NH, native high diversity mix; NL, native low diversity mix; USC, unseeded control. Note differences in scale for each graph.

Only the BLM and ARS mixes contained perennial forbs. In ARS plots during 2000 and 2001, alfalfa (Medicago sativa L. 'Rangelander') accounted for $39 \%$ and $32 \%$, respectively, of the total seeded species cover. By 2002, alfalfa cover represented only $3 \%$ of the total. In BLM plots, 'Ladak' alfalfa emerged the first year after seeding, accounting for $16 \%$ of the total seeded cover. By 2001 , alfalfa cover comprised only $1.5 \%$ and continued to decline in 2002. Alfalfa in the ARS plots was seeded at 1.5 times the pure live seed rate of that in the BLM plots (Table 1).

Although fourwing saltbush and forage kochia were seeded in the BLM and ARS mixes respectively, neither shrub emerged.
Forage kochia was seeded out of a separate box that fed directly onto the soil surface, but may have been buried too deeply or blown away on the sandy soil. The BLM fourwing seed had been warehoused for several years, which may have decreased its viability, or the seed may have been highly dormant. By 2002, both the NH and NL plots had measurable establishment of shrubs with antelope bitterbrush $\left(\right.$ mean $=412 \pm 196$ shrubs $\cdot \mathrm{ha}^{-1}$ ) and fourwing saltbush $\left(\right.$ mean $=198 \pm 78$ shrubs $\left.\bullet \mathrm{ha}^{-1}\right)$ the most prominent, and rather limited establishment for sagebrush $($ mean $=58 \pm 27$ shrubs $\left.\cdot \mathrm{ha}^{-1}\right)$. 
Table 3. Significance of vegetation variables measured in 2000, 2001, and 2002 for different seed mixes aerial seeded for fire rehabilitation in fall 1999 on a previous pinyon-juniper woodland at Mud Springs, Tintic Valley, Utah. ${ }^{1}$

\begin{tabular}{|c|c|c|c|c|c|}
\hline \multirow[b]{2}{*}{ Variable } & \multicolumn{3}{|c|}{$P$ Values } & \multicolumn{2}{|c|}{ Order (based on Tukey 0.05 ) } \\
\hline & Year & Mix & Year $\times$ Mix & Mix & Year $\times$ Mix \\
\hline \multicolumn{6}{|l|}{ Cover } \\
\hline Total vegetation & $<0.0001$ & 0.9227 & 0.7624 & - & - \\
\hline Total perennial & $<0.0001$ & 0.0027 & 0.0521 & $\mathrm{ARS}=\mathrm{BLM}>\mathrm{NH}=\mathrm{NL}>\mathrm{USC}$ & - \\
\hline Total annual & $<0.0001$ & 0.0017 & 0.0912 & $\mathrm{USC}>\mathrm{NH}=\mathrm{NL}>\mathrm{ARS}=\mathrm{BLM}$ & - \\
\hline Perennial grass & $<0.0001$ & 0.0005 & 0.0507 & $\mathrm{ARS}=\mathrm{BLM}=\mathrm{NH}=\mathrm{NL}>\mathrm{USC}$ & - \\
\hline Annual grass & 0.004 & 0.7215 & 0.6484 & - & - \\
\hline Perennial forb & $<0.0001$ & 0.1083 & 0.977 & - & - \\
\hline Annual forb & $<0.0001$ & 0.0019 & 0.0936 & $\mathrm{USC}>\mathrm{NH}=\mathrm{NL}>\mathrm{ARS}=\mathrm{BLM}$ & - \\
\hline Seeded species & $<0.0001$ & 0.505 & 0.9492 & - & - \\
\hline Bluebunch wheatgrass & $<0.0001$ & $<0.0001$ & 0.0009 & $\mathrm{NL}>\mathrm{NH}>\mathrm{ARS}=\mathrm{BLM}>\mathrm{USC}$ & $\mathrm{NL}>\mathrm{NH}>\mathrm{ARS}=\mathrm{BLM}>\mathrm{USC}$ \\
\hline Desert alyssum & $<0.0001$ & 0.002 & 0.0643 & $\mathrm{USC}>\mathrm{ARS}=\mathrm{BLM}=\mathrm{NH}=\mathrm{NL}$ & - \\
\hline Gilia spp. & $<0.0001$ & 0.7165 & 0.872 & - & - \\
\hline \multicolumn{6}{|l|}{ Frequency } \\
\hline Total vegetation & $<0.0001$ & 0.9533 & 0.9509 & - & - \\
\hline Total perennial & $<0.0001$ & 0.005 & 0.5627 & $\mathrm{ARS}=\mathrm{BLM}>\mathrm{NH}=\mathrm{NL}>\mathrm{USC}$ & - \\
\hline Total annual & $<0.0001$ & 0.0042 & 0.9429 & $\mathrm{USC}>\mathrm{NH}=\mathrm{NL}>\mathrm{ARS}=\mathrm{BLM}$ & - \\
\hline Perennial grass & $<0.0001$ & 0.0001 & 0.3903 & $\mathrm{ARS}=\mathrm{BLM}=\mathrm{NH}=\mathrm{NL}>\mathrm{USC}$ & - \\
\hline Annual grass & $<0.0001$ & 0.1212 & 0.173 & - & - \\
\hline Perennial forb & $<0.0001$ & 0.1788 & 0.8311 & - & - \\
\hline Annual forb & $<0.0001$ & 0.0136 & 0.9422 & $\mathrm{USC}>\mathrm{ARS}=\mathrm{BLM}>\mathrm{NH}=\mathrm{NL}$ & - \\
\hline Seeded species & $<0.0001$ & 0.8467 & 0.3379 & - & - \\
\hline Bluebunch wheatgrass & $<0.0001$ & 0.0004 & 0.0015 & $\mathrm{NH}=\mathrm{NL}>\mathrm{ARS}=\mathrm{BLM}=\mathrm{USC}$ & $\mathrm{NH}>\mathrm{NL}>\mathrm{BLM}>\mathrm{ARS}>\mathrm{USC}$ \\
\hline Desert alyssum & $<0.0001$ & 0.0167 & 0.9963 & $\mathrm{USC}>\mathrm{NH}=\mathrm{NL}>\mathrm{ARS}=\mathrm{BLM}$ & - \\
\hline Gilia spp. & $<0.0001$ & 0.3933 & 0.627 & - & - \\
\hline \multicolumn{6}{|l|}{ Density } \\
\hline Total vegetation & $<0.0001$ & 0.0421 & 0.2763 & $\mathrm{USC}>\mathrm{ARS}=\mathrm{NH}=\mathrm{NL}>\mathrm{BLM}$ & - \\
\hline Total perennial & $<0.0001$ & 0.3018 & 0.7225 & - & - \\
\hline Total annual & $<0.0001$ & 0.0098 & 0.3039 & $\mathrm{USC}>\mathrm{NH}=\mathrm{NL}>\mathrm{ARS}=\mathrm{BLM}$ & - \\
\hline Perennial grass & $<0.0001$ & 0.217 & 0.9047 & - & - \\
\hline Annual grass & 0.0008 & 0.608 & 0.715 & - & - \\
\hline Perennial forb & 0.0045 & 0.1827 & 0.7401 & - & - \\
\hline Annual forb & $<0.0001$ & 0.0113 & 0.3088 & $\mathrm{USC}>\mathrm{NH}=\mathrm{NL}>\mathrm{ARS}=\mathrm{BLM}$ & - \\
\hline Seeded species & $<0.0001$ & 0.9311 & 0.2608 & - & - \\
\hline Bluebunch wheatgrass & $<0.0001$ & 0.0019 & 0.0018 & $\mathrm{NL}>\mathrm{NH}>\mathrm{ARS}=\mathrm{BLM}>\mathrm{USC}$ & - \\
\hline Desert alyssum & $<0.0001$ & 0.0108 & 0.3019 & $\mathrm{USC}>\mathrm{NH}=\mathrm{NL}>\mathrm{ARS}=\mathrm{BLM}$ & - \\
\hline Gilia spp. & $<0.0001$ & 0.3721 & 0.6059 & - & 一 \\
\hline \multicolumn{6}{|c|}{ Degrees of freedom (seeded species category) } \\
\hline Numerator & 2 & 3 & 6 & & \\
\hline Denominator & 32 & 12 & 32 & & \\
\hline \multicolumn{6}{|c|}{ Degrees of freedom (all others) } \\
\hline Numerator & 2 & 4 & 8 & & \\
\hline Denominator & 40 & 16 & 40 & & \\
\hline
\end{tabular}

${ }^{1}$ ARS indicates Agricultural Research Service; BLM, Bureau of Land Management; NH, native high; NL, native low; USC, unseeded control. Order for the year $\times$ mix column is for 2002.

\section{Aerial Seeding}

Soil texture did not vary significantly $(P>0.05)$ among treatments or replications. Point estimation of soil movement for the aerial seeding showed both slight erosion and deposition with no significant differences among seed mixes or with the unseeded control $(<2 \mathrm{~mm})$.

All vegetation variables varied significantly by year $(P<0.005)$ but there were no significant year $\times$ mix inter- actions, except for bluebunch wheatgrass cover and frequency $(P>0.05$, Table 3$)$. Seeded species cover, frequency, and density were similar for all seeding mix plots and were indicative of successful stand establishment $\left(>8\right.$ plants $\cdot \mathrm{m}^{-2}$, Fig. 2). Seeded species canopy cover for 2002 ranged from $9.5 \%$ in the NH to $12.3 \%$ in the BLM mix. Despite the lack of rain in 2001, seeded species cover more than doubled in all treatments compared to 2000. Residual perennial plant 
Jericho - Drill Seeding

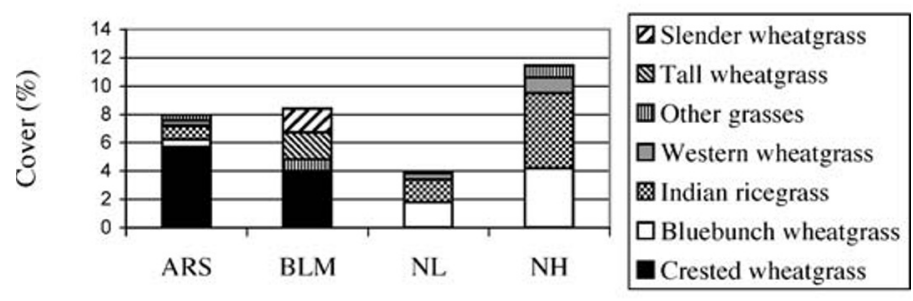

Mud Springs - Aerial Seeding

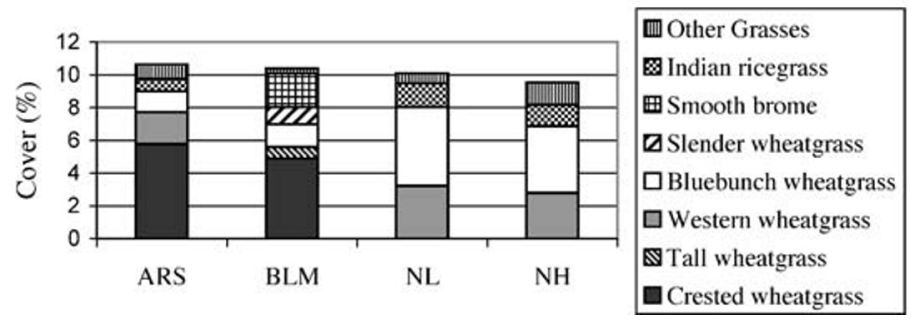

Figure 3. Seeded species composition 2 years after seeding for drillseeded and aerially seeded plots in Tintic Valley, Utah. Other grasses include unknown wheatgrass, Great Basin wildrye, Russian wildrye, Sandberg bluegrass, squirreltail, and needle and thread. ARS indicates Agricultural Research Service mix; BLM, Bureau of Land Management mix; NL, native low diversity mix; $\mathrm{NH}$, native high diversity mix.

cover was $<2.2 \%$ in all treatments except USC, in which it was $6.8 \%$. Higher residual cover in USC plots may be because these areas were not chained.

Total annual species cover, frequency, and density were highest in USC plots, intermediate in NH and NL plots, and lowest in ARS and BLM plots (Fig. 2, Table 3). Cheatgrass encroachment was minimal in all treatments $(<1 \%$ canopy cover) including USC. Annual forbs desert alyssum and gilia came in quickly following the burn, but gilia was nearly absent after 1 year. Desert alyssum cover and density increased drastically during 2001, but by 2002 had decreased; desert alyssum was most abundant in USC plots, where it accounted for nearly $40 \%$ of the total cover.

As with the drill-seeded sites, crested wheatgrass had greater cover, frequency, and density than other seeded species in the BLM and ARS plots (Fig. 3). Indian ricegrass, 'Secar' Snake River bluebunch wheatgrass, and western wheatgrass were also common in the ARS plots, whereas smooth brome and crested wheatgrass were most dominant in BLM plots. NL and $\mathrm{NH}$ plots were dominated by bluebunch wheatgrass, followed by western wheatgrass and Indian ricegrass. Alfalfa was included only in the ARS aerial seed mix, and emergence was nominal. Cover increased slightly from 2000 to 2001 but was still $<0.5 \%$. By 2002, alfalfa was almost completely absent.

Antelope bitterbrush had lower establishment in the aerial than drill seeding $\left(\right.$ mean $=25 \pm 9$ shrubs $\cdot h^{-1}$ for all 4 mixes), whereas sagebrush had greater establishment on NL and $\mathrm{NH}$ plots in the aerial (mean $=237 \pm 111$ shrubs $\cdot \mathrm{ha}^{-1}$ ) than in the drill seeding. Although the dribbler mix of fourwing saltbush and antelope bitterbrush was seeded in all seeded plots, fourwing saltbush established better in the NH and NL plots $\left(\right.$ mean $=133 \pm 31$ shrubs $\left.\cdot \mathrm{ha}^{-1}\right)$ than in the BLM and ARS mix plots (mean $=35 \pm 15$ shrubs $\cdot \mathrm{ha}^{-1}$ ). Forage kochia in the ARS mix showed little success the first year and was completely absent the second year. Wyoming big sagebrush was successful in both native seed treatments, but densities in the NH plots were greater than in the NL plots in 2002 $\left(395 \pm 184\right.$ shrubs $\cdot \mathrm{ha}^{-1}$ and $\left.79 \pm 67 \mathrm{shrubs} \cdot \mathrm{ha}^{-1}\right)$.

\section{DISCUSSION}

\section{Drill Seeding}

Overall, the ARS, BLM, and NH mixes had similar success. Seeded species increased in cover by the second year after seeding, indicating successful stand establishment. This increase in cover and successful establishment was associated with rainfall in March, April, and July of 2001, even though annual precipitation was well below average that year and the following year (Fig. 1). Perennial grass cover, frequency, and density were in fact highest in the $\mathrm{NH}$ mix by the third year (Fig. 2; Table 2). This is likely a result of the higher seeding rates used for the $\mathrm{NH}$ mix (about 2 times the rate of the other mixes). The lower establishment from the NL treatment in the drill seeding is difficult to explain. Indian ricegrass and bluebunch wheatgrass had the greatest emergence and survival of any species planted in both NL and NH plots, but emergence from the NL mix was less than half that found in the NH. Because seeding rates for bluebunch wheatgrass and Indian ricegrass were identical in the 2 native mixes, similar emergence was expected. Both mixes were taken from the same seed lots and both drills were carefully calibrated.

Although crested wheatgrass established best in both the ARS and the BLM seedings, native Indian ricegrass also established in the ARS mix. Waldron et al. (2005) showed that native species sown with aggressive introduced species such as crested wheatgrass are limited in establishment, but can coexist when sown with species like Russian wildrye that are slower to establish. Additional monitoring of our plots is needed to determine compatibility over time of native species sown with crested wheatgrass in the ARS mix on this site.

The high mortality of alfalfa, as seen in the drill seeding during the first 1-3 years after seeding, is normal for alfalfa in rangeland seedings (Rosenstock and Stevens 1989). Once well established, alfalfa may have high persistence on rangelands. Rumbaugh and Pedersen (1979) reported successful establishment of alfalfa stands in rangeland seedings in northern Utah 20 years after seeding.

Sagebrush establishment was limited (year 2002, NL $=20$ plants $\cdot \mathrm{ha}^{-1}, \mathrm{NH}=59$ plants $\cdot \mathrm{ha}^{-1}$ ). To reduce competition with seeded grasses and encourage shallow seed burial, sagebrush was seeded in rows with shrubs only and seed tubes for these rows were pulled to allow seed to fall on the soil surface. Sagebrush might have established better if seeds had been pressed into the soil surface (Boltz 1994; Stevens and Monsen 2004; Shaw et al. 2005).

Drill seeding is often favored in postfire rehabilitation because it provides a means of distributing and covering the seed in a single operation (Vallentine 1989). Compared to broadcast seeding, drill seeding generally favors infiltration and moisture storage, offers some wind protection, produces a more 
uniform stand, and results in stands reaching full production sooner (Vallentine 1989; Whisenant 1999). Seedling recruitment during either natural or artificial revegetation is a result of the number of seeds in favorable microsites, or "safe sites," in the seedbed rather than the total number of available seeds (Harper et al. 1965; Young 1988). A critical component of "safe sites" includes proper seeding depth for each species in the mix. Drill seeding into softer seed beds can cause the seed to be buried too deeply, inhibiting seedling emergence and survival. The use of depth regulator bands on the drill disks helps, but only partially alleviates the problem of deep burial in soft seedbeds (Vallentine 1989). The drills used in this study were not equipped with depth bands. We hypothesize that lack of depth bands combined with sandy soils and the positioning of drill rows perpendicular to the prevailing winds resulted in seeds being planted or inadvertently buried deeper than was optimal, especially in 2 of the 5 replications.

Seeding depth is often a compromise of recommended seeding depths of all species used in a mix. Generally, larger seeds have greater energy reserves and can be buried deeper and still emerge and survive (Hull 1966; Lawrence et al. 1991; Bloomquist and Lyon 1995; USDA-NRCS 2001). Our study showed higher success of some individual species with large seed sizes such as Indian ricegrass and tall wheatgrass. Both native mixes showed a considerable contribution from 'Nezpar' Indian ricegrass in both years. Although the soil of replications 1-3 was less sandy than that of replications 4 and 5, where the seeding failed, it was sandy enough that we suspect that the seeds of many species except Indian ricegrass were buried too deep. Indian ricegrass is unique in its ability to germinate and emerge from greater depths than most other seeded species (USDA-NRCS 2001). Several studies have shown Indian ricegrass emergence from an average of $5 \mathrm{~cm}$ and up to $15 \mathrm{~cm}$ in sandy soils. (Kisinger 1962; Young et al. 1969, 1983, 1994). Studies to determine actual seeding depth following treatment may help explain revegetation results (Winkel and Roundy 1991). Even though germination of some species was likely inhibited by deep burial at the Jericho site, enough species established on 3 of the 5 replications to compete with annuals. Following fire, first-year annuals are often robust with relatively large canopies, but over time, as seeds disperse and populations become more dense, individual weed canopies decrease. As seeded perennial species continue to expand their root systems and increase their competitive ability, we expect long-term suppression of annuals and return of ecosystem function in the absence of further disturbance.

Our results suggest that successful establishment of some native species on Wyoming big sagebrush sites with similar soils and precipitation may require a higher seeding rate or more shallow seeding than required by some introduced species.

\section{Aerial Seeding/Chaining}

The lack of significant differences in cover, frequency, and density of seeded species among mixes in all years shows the ability of native seed mixes to establish and survive as well as introduced species under the study period precipitation and following proper seeding methods, relatively high seeding rates, and soil coverage from chaining.
In contrast to the drill-seeded sites, the NL mix established as well when aerially seeded as the NH mix. This is somewhat surprising because the NL seeding rate for grasses was about half that of the NH mix. Sagebrush seeding rates in NH plots were double those of NL, and densities in $\mathrm{NH}$ plots were 5 times greater than in NL plots $\left(395\right.$ vs. 79 plants ha ${ }^{-1}$ for 2002). This suggests that when chaining is employed, higher seeding rates for native grasses may not increase success, but higher seeding rates for sagebrush may be necessary to achieve desired results. Following aerial seeding, covering of seed by chaining has proven necessary for successful seeding at elevations less than around $2000 \mathrm{~m}$ in this area (Ott 2001; Ott et al. 2003). However, Juran et al. (2005) found similar firstyear establishment success of chained and unchained aerialbroadcast fire rehabilitation seedings in the Henry Mountains above $2000 \mathrm{~m}$. Most seed mixes use several species with differing seeding depth requirements. Chaining creates numerous microsites at different depths, which favors multiple species requirements (Stevens 1999). Chaining may have provided the necessary microsite modifications that enabled grasses in the NL mix to be successful despite the lower seeding rate and increased sagebrush germination and establishment compared to drilled sites. In addition, chaining leaves debris on the ground to catch runoff and sediment, which can increase infiltration and reduce the total amount of soil loss across hillslopes (Davenport et al. 1998; Roundy and Vernon 1999). Soil loss may eventually cause an area to cross an abiotic threshold at which little or no vegetation can establish and survive without extensive site modifications (Whisenant 1999).

Broadcast seeding using aircraft is advantageous because of increased efficiency and reduced costs (Vallentine 1989; Whisenant 1999). We opted to use a helicopter rather than a fixed-wing airplane because helicopters are capable of flying closer to the ground and at slower speeds, and are easier to land and refill with seed, which makes them better adapted for seeding the relatively narrow, adjacent plots in this study. They are generally capable of producing a more uniform rate and distribution of seed across a study area, provided that the wind is not over about $15 \mathrm{~km} \cdot \mathrm{h}^{-1}$ or turbulent and shifting (Vallentine 1989). When sagebrush seed is added to the mix of a broadcast seeder, agitation is recommended to facilitate even flow of seeds out of the opener. Broadcast seeding does not enable full control over seed spacing and stand density, and generally results in decreased germination and establishment because of lack of seed burial and loss of seed to predators. Compared to drilling, broadcasting requires higher seeding rates to compensate for reduced germination and increased predation. Dalzell (2004) found similar and limited densities of sagebrush plants on aerially seeded and nonseeded fire rehabilitation sites in southern Idaho. Aerially broadcasting sagebrush without providing some seed coverage is likely to fail. Seeding into prepared seedbeds, covering the seed, and firming the soil reduce these problems for many species (Whisenant 1999). Although broadcast seeding by aircraft often costs slightly less per acre than drill seeding, this cost is generally offset by the $50 \%$ to $75 \%$ more seed required with broadcasting (Vallentine 1989). This cost increase is magnified when using native species, which are substantially more expensive than introduced species (Table 1). 


\section{MANAGEMENT IMPLICATIONS}

Both the drill seeding and the aerial seeding demonstrated the ability of native species to establish in a semiarid area using common seeding methods and proper seeding rates. By the end of the project, both drill-seeded and aerially seeded sites had fewer annual and more perennial species compared to the unseeded controls. Both the ARS and the BLM mixes produced consistently successful stands on both drilled and aerially seeded areas using moderate seeding rates. Although results with the NH and NL mixes were similar to those seen in the ARS and BLM mixes, higher seeding rates for the drilled area and much higher costs for both areas were required to obtain these results. If native seed costs remain high, the introduced species in the ARS and BLM mixes will continue to play an important role in fire rehabilitation plantings to prevent weed invasion, and possibly act as bridging communities to subsequent native-seeded communities (Cox and Anderson 2004). In drill-seeded and aerially seeded areas, several grass species in the NH mix, including Sandberg bluegrass (Poa secunda J. Presl), Great Basin wildrye (Leymus cinereus [Scribn. and Merr.] A. Löve), squirreltail (Elymus elymoides [Raf.] Swezey), and needle and thread (Hesperostipa comata [Trin. and Rupr.] Barkworth), emerged but did not contribute significantly to the overall seeded species cover. A better understanding of which native species and source-identified populations are most likely to establish on specific sites and soils would possibly allow a lighter seeding rate and decrease costs by omitting costly plant materials that are less likely to establish. On the other hand, including a richer group of species and plant materials may increase probability of success across a range of years on sites with high variability in timing and amount of precipitation and favorable temperatures.

The scale of this project should allow land managers to better extrapolate these results to landscape-scale fire rehabilitation efforts using similar techniques and on similar sites. However, it is important to note that conclusions drawn in the first years after rehabilitation projects are often preliminary. Soil stabilization, resistance to weed invasion, and protection of life are a few of the preliminary goals of postfire rehabilitation administered by emergency fire rehabilitation funds. Long-term goals of these treatments focus more on continued stability, species persistence, and ecosystem functionality. Continued monitoring is necessary to best determine the success of this and other large-scale rehabilitation projects (McArthur 2004). Although this study was replicated within the 2 study sites, the study was not replicated across other landscapes and seeding treatments were not replicated over other years. Replication over similar sites within additional years for similar fires is difficult given the nature of wildfire. Results from this study apply best to similar sites and postseeding precipitation patterns.

\section{ACKNOWLEDGMENTS}

The authors would like to thank Harvey Gates and Pat Fossie, Fillmore Field Office, Bureau of Land Management at the time of the study for seed purchases and technical support. We thank Steve Monsen for advice on seed mixes, drill calibration, and study site selection. We thank Howard Horton and Ronald Reed, USDA-Agricultural Research Service, for help in seeding the experiment, and John Fairchild, Utah Division Wildlife Resources, for seeding and technical support. We also appreciate substantial field support from Mark Farmer, Utah Department of Natural Resources, Jason Vernon and Ashley Green, Utah Division of Wildlife Resources, and Brigham Young University students.

\section{LITERATURE CITED}

Asay, K. H., W. H. Horton, K. B. Jensen, and A. J. Palazzo. 2001. Merits of native and introduced Triticae grasses on semiarid rangelands. Canadian Journal of Plant Science 81:45-52.

BLOOMQUIST, K. W., AND G. E. LYON. 1995. Effects of soil quality and depth on seed germination and seedling survival at the Nevada test site. In: B. A. Roundy, E. D. McArthur, J. S. Haley, and D. K. Mann [Comps.]. Proceedings-Wildland Shrub and Arid Land Restoration Symposium; 19-21 October 1993; Las Vegas, NV. Ogden, UT: US Department of Agriculture, Forest Service, Rocky Mountain Research Station. General Technical Report INT-GTR-315. p 57-62.

Boltz, M. 1994. Factors influencing postfire sagebrush regeneration in southcentral Idaho. In: S. B. Monsen and S. G. Kitchen [comps.]. ProceedingsEcology and Management of Annual Rangelands; 18-22 May 1992; Boise, ID. Ogden, UT: US Department of Agriculture, Forest Service, Rocky Mountain Research Station. General Technical Report INT-GTR-313. p 280-290.

Bouyoucos, G. J. 1962. Hydrometer method improved for making particle size analysis of soil. Agronomy Journal 54:464-465.

Brown, R. W., and M. C. Amacher. 1999. Selecting plant species for ecological restoration: a perspective for land managers. In: L. K. Holzworth and R. W. Brown [comps.]. Proceedings-Revegetation With Native Species; 12-15 November 1997; Fort Lauderdale, FL. Ogden, UT: US Department of Agriculture Forest Service, Rocky Mountain Research Station. Proc. RMRSP-8. p 1-16.

Cox, R. D., AND V. J. Anderson. 2004. Increasing native diversity of cheatgrassdominated rangeland through assisted succession. Journal of Range Management 57:203-210.

DalzelL, C. R. 2004. Post-fire establishment of vegetation communities following reseeding on southern Idaho's Snake River Plain [thesis]. Boise, ID: Boise State University. $112 \mathrm{p}$.

Davenport, D. W., D. D. Breshears, B. P. Wilcox, and C. D. Allen. 1998. Viewpoint: sustainability of pinyon-juniper ecosystems-a unifying perspective of soil erosion thresholds. Journal of Range Management 51:231-240.

Hadley, R. F., And G. C. Lusby. 1967. Runoff and hillslope erosion resulting from a high-intensity thunderstorm near Mack, Western Colorado. Water Resources Research 3:139-143.

HaIGHT, M. J. 1977. The use of erosion pins in the study of slope evolution. In: Shorter Technical Methods (II), Technical Bulletin No. 18. Geo Books, Norwich, UK.: British Geomorphological Research Group. p 31-49.

Harper, J. L., J. T. Williams, and G. R. Sagar. 1965. The behavior of seeds in soil. I. The heterogeneity of soil surfaces and its role in determining the establishment of plants from seed. Journal of Ecology 53:273-286.

Huber-Sannwald, E., and D. A. Pyke. 2005. Establishing native grasses in a big sagebrush dominated site: an intermediate restoration step. Restoration Ecology 13:292-301.

HuLL, A. C., JR. 1966. Emergence and survival of intermediate wheatgrass and smooth brome seeded on a mountain range. Journal of Range Management 19:279-283.

Juran, C., B. Roundy, J. Davis, and L. Armstrong. 2005. Initial fire rehabilitation success on the Henry Mountains, Utah. Society for Range Management 58th Annual Meeting. 5-11 February 2005; Fort Worth, TX. Denver, C0: Society for Range Management. Abstract 185.

KIsInger, F. E. 1962. The relationship between depth of planting and maximum foliage height of seedlings of Indian ricegrass. Journal of Range Management 15:10-13.

Lawrence, T., C. D. Ratzlaff, and P. G. Jefferson. 1991. Emergence of several Triticeae range grasses influenced by depth of seed placement. Journal of Range Management 44:186-189.

Littell, R. C., G. A. Milliken, W. W. Stroup, and R. D. Wolfinger. 1996. SAS system for mixed models. Cary, NC: SAS Institute Inc. 633 p. 
MacDonald, L. 1999. Wildfire rehabilitation in Utah. In: S. B. Monsen and R. Stevens [comps.]. Proceedings-Ecology and Management of PinyonJuniper Communities Within the Interior West. 15-18 September 1997; Provo, UT. Ogden, UT: US Department of Agriculture, Forest Service, Rocky Mountain Research Station. RMRS-P-9. p 410-411.

McArthuR, T. 0. 2004. Emergency fire rehabilitation of BLM lands in the Great Basin: revegetation \& monitoring [thesis]. Corvallis, OR: Oregon State University. $65 \mathrm{p}$.

Monsen, S. B., AND S. G. Kitchen [Comps.]. Proceedings-Ecology and Management of Annual Rangelands; 18-22 May 1992; Boise, ID. Ogden, UT: US Department of Agriculture, Forest Service, Rocky Mountain Research Station. General Technical Report INT-GTR-313. $416 \mathrm{p}$.

Mosley, J. C., S. C. Bunting, and M. HiRonaka. 1986. Determining range condition from frequency data in mountain meadows of central Idaho. Journal of Range Management 39:561-565.

[NIFC] National Interagency Fire Center. 2005. Wildland fire statistics. Available at: http://www.nifc.gov/stats/wildlandfirestats.html. Accessed 14 March 2005.

Noss, R. F., E. T. LAROE III, AND J. M. Scott. 1995. Endangered ecosystems of the United States: A preliminary assessment of loss and degradation. Washington, DC: US Department of Interior, National Biological Service. Biological Report 28. $81 \mathrm{p}$.

0тT, J. E. 2001. Vegetation of chained and non-chained rangelands following wildfire andrehabilitation in west-central Utah [thesis]. Provo, UT: Brigham Young University. $79 \mathrm{p}$.

OtT, J. E., E. D. McArthur, And B. A. Roundy. 2003. Vegetation of chained and non-chained seedings after wildfire in Utah. Journal of Range Management 56:81-91.

Plummer, P. A., D. R. Christensen, and S. B. Monson. 1968. Restoring big-game range in Utah. Salt Lake City, UT: Utah Division of Fish and Game. Pub. 68-3. $183 \mathrm{p}$.

Pyke, D. A., T. O. McArthur, K. S. Harrison, and M. Pellant. 2003. Coordinated intermountain restoration project-fire, decomposition and restoration. In N. Allsop, A. R. Palmer, S. J. Milton, K. P. Kirkham, G. I. H. Kerley, C. R. Hurt, and C. J. Brown [EDS.]. Proceedings, 7th International Rangeland Congress; 26 July1 August 2003; Durban, South Africa. Denver, C0: Society for Range Management. p 1116-1124.

Roundy, B. A., N. L. Shaw, and D. T. Booth. 1997. Using native seeds on rangelands. In: N. L. Shaw and B. A. Roundy [Comps.]. Proceedings-Using Seeds of Native Species on Rangelands; 16-21 February 1997; Rapid City, SD. Ogden, UT: US Department of Agriculture, Forest Service, Rocky Mountain Research Station. General Technical Report INT-GTR-372. p 1-8.

Roundy, B. A., AND J. L. Vernon. 1999. Watershed values and conditions associated with pinyon-juniper communities. In: S. B. Monsen and R. Stevens [Comps.] Proceedings-Ecology and Management of Pinyon-Juniper Communities Within the Interior West; 15-18 September 1997; Provo, UT. Ogden, UT: US Department of Agriculture, Forest Service, Rocky Mountain Research Station. RMRS-P-9. p 172-187.

Richards, R. T., J. C. Chambers, And C. Ross. 1998. Use of native plants on federal lands: policy and practice. Journal of Range Management 51:625-632.

Rosenstock, S. S., AND R. SteVENS. 1989. Herbivore effects on seeded alfalfa at four pinyon-juniper sites in central Utah. Journal of Range Management 42:483-490.

Rumbaugh, M. D., and M. W. Pedersen. 1979. Survival of alfalfa in five semiarid range seedings. Journal of Range Management 32:48-51.

SAS INSTITUTE, INC. 1987. SAS/STAT guide for personal computers, Version 6. Cary, NC: SAS Institute, Inc. 1028 p.

Shaw, N. L., A. M. DeBolt, and R. Rosentreter. 2005. Reseeding big sagebrush: techniques and issues. In: N. L. Shaw, M. Pellant, and S. B. Monsen [comps.] Sage-Grouse Habitat Restoration Symposium Proceedings; 4-7 June 2001; Boise, ID. Fort Collins, C0: US Department of Agriculture, Forest Service, Rocky Mountain Research Station. RMRS-P-38. p 99-108.

Smith, S. D., S. C. Bunting, and M. HiRonaka. 1986. Sensitivity of frequency plots for detecting vegetation change. Northwest Science 60:279-286.

Smith, S. D., S. C. Bunting, AND M. HiRonaka. 1987. Evaluation of the improvement in sensitivity of nested frequency plots to vegetational change by summation. Great Basin Naturalist 47:299-307.
Stevens, R. 1999. Mechanical chaining and seeding. In: S. B. Monsen and R. Stevens [Comps.]. Proceedings-Ecology and Management of Pinyon-Juniper Communities Within the Interior West; 15-18 September 1997; Provo, UT. Ogden, UT: US Department of Agriculture, Forest Service, Rocky Mountain Research Station. RMRS-P-9. p 281-284.

Stevens, R., and S. B. Monsen. 2004. Chapter 18. Guidelines for restoration and rehabilitation of principle plant communities. In: S. B. Monsen, R. Stevens, and N. L. Shaw [Comps.]. Restoring western ranges and wildlands. Volume 1. Fort Collins, CO: US Department of Agriculture, Forest Service, Rocky Mountain Research Station. General Technical Report RMRS-GTR-136vol-1. p 199-294.

Takel A., S. Kobaski, and Y. Fukushima. 1981. Erosion and sediment transport measurement in a weathered granite mountain area. In: Proceedings-Erosion and Sediment Transport Measurement Symposium; 22-26 June 1981; Florence, Italy. Washington, DC: IAHS. Publ. no. 133. p 63-81.

[USDA-FS] United States Department of Agriculture-Forest Service. 2005. Burned area emergency response. Available at: http://www.fs.fed.us/biology/ watershed/burnareas/background.html. Accessed March 2005.

[USDA-NRCS] United States Department of Agriculture-Natural Resource Conservation Service Soll Survey. 1984. Soil survey of Juab Co. Utah. Salt Lake City, UT: US Department of Agriculture Soil Conservation Service. 359 p.

[USDA-NRCS] United States Department of Agriculture-Natural Resource Conservation Service. 2001. The PLANTS database, version 3.1. Available at: http://plants.usda.gov. Accessed 22 November 2004.

[USDI-BLM] United States Department of the Interior-Bureau of Land Management. 1999. Emergency fire rehabilitation handbook. Washington, DC: US Department of the Interior. USDI BLM H-1742. $59 \mathrm{p}$.

Vallentine, J. F. 1989. Range development and improvements. 3rd ed. San Diego, CA: Academic Press. 524 p.

Waldron, B. L., T. A. Monaco, K. B. Jensen, R. D. Harrison, A. J. Palazzo, and J. D. KuLBETH. 2005. Coexistence of native and introduced perennial grasses following simultaneous seeding. Agronomy Journal 97:990-996.

Waters, C. M., AND N. L. Shaw. 2003. Developing native grass seed industries for revegetation in Australia and the western United States: a contrast in production and adoption. African Journal of Range and Forage Science 20:159.

WeSt, N. E., AND J. A. Young. 2000. Intermountain valleys and lower mountain slopes. In: M. G. Barbour and W. D. Billings [EDs.]. North American terrestrial vegetation. 2nd ed. Cambridge, UK: Cambridge University Press. $p$ 255-284.

Western Regional Climate Center. 2005. Historical Climate Information. Available at: http://www.wrcc.dri.edu/. Accessed October 2005.

WhISENANT, S. G. 1999. Repairing damaged wildlands: a process-oriented, landscape-scale approach. Cambridge, UK: Cambridge University Press. $312 \mathrm{p}$.

Wiedemann, H. 2005. Revegetation equipment catalog. Available at: http://revegcatalog.tamu.edu. Accessed 14 March 2005.

WinkeL, V. K., AND B. A. Roundy. 1991. Technical notes: a technique to determine seed location in relation to seedbed preparation treatments. Journal of Range Management 44:91-92

Young, J. A., R. A. Evans, and R. E. Eckert, JR. 1969. Emergence of medusahead and other grasses from four seeding depths. Weed Science 17:376-379.

Young, J. A., AND R. A. Evans. 1978. Population dynamics after wildfires in sagebrush grasslands. Journal of Range Management 31:283-289.

Young, J. A., R. A. Evans, AND B. A. Roundy. 1983. Quantity and germinability of Oryzopsis hymenoides seed in Lahontan sands. Journal of Range Management 36:82-86.

YounG, J. A. 1988. Seedbeds as selective factors in the species composition of rangeland communities. In: P. T. Tueller [ED.]. Vegetation science applications for rangeland analysis and management. Dordrecht, The Netherlands: Kluwer Academic Publishers. p 171-188.

Young, J. A., R. R. Blank, W. S. Longland, and D. E. Palmquist. 1994. Seeding Indian ricegrass in an arid environment in the Great Basin. Journal of Range Management 47:2-7. 